\title{
eNOS Gene Variant in Patients with Coronary Artery Disease
}

\author{
Milad Abolhalaj, Mahsa M. Amoli, and Parvin Amiri \\ Endocrinology and Metabolism Research Center (EMRC), Tehran University of Medical Sciences, Tehran 14114, Iran \\ Correspondence should be addressed to Mahsa M. Amoli; amolimm@tums.ac.ir
}

Received 4 September 2012; Revised 21 October 2012; Accepted 27 October 2012

Academic Editor: José Luis Martín-Ventura

\begin{abstract}
Copyright (c) 2013 Milad Abolhalaj et al. This is an open access article distributed under the Creative Commons Attribution License, which permits unrestricted use, distribution, and reproduction in any medium, provided the original work is properly cited.
\end{abstract}

\begin{abstract}
Subject \& Aim. Endothelial nitric oxide synthase (eNOS) is one of the most important candidate genes in CAD. A functional polymorphism within eNOS gene is a $27 \mathrm{bp} \mathrm{VNTR} \mathrm{on} \mathrm{its} \mathrm{intron} 4$ which has been shown to be associated with various diseases. In this study we investigated eNOS VNTR polymorphism in addition to eNOS gene expression profile in patients with CAD. Material and Methods. The study comprised patients with angiographically confirmed CAD $\left(\mathrm{CAD}^{+}\right)$and individuals with normal coronary as $\mathrm{CAD}^{-}$. eNOS VNTR polymorphism frequencies were determined in both groups. In addition eNOS gene expression profile was examined using a quantitative real-time PCR. Results. We have found that aa genotype was significantly increasing the risk of CAD in our patients (aa versus $\mathrm{ab}+\mathrm{bb}, P=0.02$, OR $=3.5 ; 95 \% \mathrm{CI}:=0.98$ to 16.2 ). The differences in eNOS expression were not significant between patients and normal group; however in $\mathrm{CAD}^{+}$patients eNOS expression was higher than the expression level of patients carrying other genotypes $(P=0.16)$. Conclusion. We have observed that eNOS gene polymorphism was associated with CAD in angiography-confirmed patients. However, the difference in eNOS gene expression was not statistically significant between patients and control which might be due to the contribution of other confounding factors which require further investigations.
\end{abstract}

\section{Introduction}

Coronary artery disease $(\mathrm{CAD})$ is one of the leading causes of death in the world. Familial aggregation of CAD indicates the contribution of genetic factors which might be involved in disease development. Genome-wide association studies have identified approximately 34 distinct loci in correlation with CAD [1]. Nitric oxide synthase (NOS) is one of the most important candidate genes in CAD. It is synthesizing $\mathrm{NO}$ in a catabolic reaction in presence of L-arginine [2]. The gene is located on chromosome $7 \mathrm{q} 36$ and is comprised of 3 isoforms in mammalian cells: neuronal (nNOS, type I), inducible (iNOS, type II), and endothelial (eNOS, type III). Most circulating NO is produced by these three isoforms $[3,4]$. In all isoforms calmodulin domains become activated in the presence of $\mathrm{Ca}^{+2}$ resulting in enzyme activation [5]. Additionally, in the presence of stress, phosphorylations at Ser1177 of eNOS lead to $\mathrm{Ca}^{+2}$ sensitiveness which in turn results in enzyme activation $[6,7]$.

Vascular endothelial growth factor (VEGF) can also give rise to eNOS enzyme activation due to Ser/Thr kinase (Akt) function [8]. NO has essential role in vasodilatation via soluble guanylyl cyclase and cyclic GMP generation in smooth muscle cells [9-11]. Likewise, NO can inhibit leucocyte adhesion to the vessel wall by either interfering with the ability of the leucocyte adhesion molecule CD11/CD18 to bind to the endothelial cell surface or by suppressing CD11/CD18 expression on leucocytes [12-15] resulting in atheroma formation which in turn contributes to the formation of a soft plaque which increases the risk of unstable angina, thrombosis, and acute myocardial infarction [16].

eNOS-derived NO also contributes to the prevention of apoptosis in endothelial cells by reactive oxygen species (ROS) and Angiotensin II (AT) [17]. Furthermore, in presence of NO, smooth muscle cell proliferation is inhibited through the prohibition of DNA synthesis $[18,19]$. Likewise, endothelium-derived $\mathrm{NO}$ acts as potent regulator of blood pressure and blood flow [20]. Increased level of iron could lead to free hydroxy radicals production resulting in LDL oxidation [21] which is specified as a key factor in pathogenesis of atherosclerosis and cardiovascular diseases [22] due to a lipid accumulation in macrophages and foam cells, which is toxic for cells [23]. Moreover, NO's protective effects on animal endothelium have also been demonstrated in mice 
with impaired eNOS function giving rise to hypertension [24] which has a close correlation with CAD [25]. Previous studies have reported eNOS polymorphisms as probable risk factors in the CAD pathogenesis [26]. A functional polymorphism within eNOS gene is a $27 \mathrm{bp} \mathrm{VNTR} \mathrm{on} \mathrm{its} \mathrm{intron} \mathrm{4,} \mathrm{which} \mathrm{is}$ comprised of 2 alleles $(4 \mathrm{a}, 4 \mathrm{~b})$, and has been studied in several conditions [27]. Various frequencies for this polymorphism have been reported in different ethnic groups $[27,28]$; in this study we investigated eNOS $27 \mathrm{bp} \mathrm{VNTR} \mathrm{polymorphism} \mathrm{in}$ addition to eNOS gene expression profile in Iranian $\mathrm{CAD}^{+}$ people in comparison with $\mathrm{CAD}^{-}$patients.

\section{Materials and Methods}

DNA was extracted from anticoagulated blood collected in EDTA tubes using salting-out method. Genotyping was carried out as follows: A total of $20 \mathrm{ng}$ genomic DNA was amplified in a $10 \mu \mathrm{L}$ final PCR reaction volume containing 5 pmol of each primers: forward primer 5 '-GGG AACCTCAGCCCAGTAGTGAA-3' and reverse primers $5^{\prime}$ TCTCTTAGTGCTGTGGTCAC-3', $200 \mathrm{mmol}$ of dNTPs, $10 \mathrm{uL} \mathrm{NH} \mathrm{NH}_{4}$ buffer, and 0.6 units of Taq polymerase. The DNA was denatured at $95^{\circ} \mathrm{C}$ for $2 \mathrm{~min}$, and temperature cycling was set at $95^{\circ} \mathrm{C}$ for $45 \mathrm{~s}, 58^{\circ} \mathrm{C}$ for $45 \mathrm{~s}$, and $72^{\circ} \mathrm{C}$ for $45 \mathrm{~s}$ for 40 cycles followed by a final extension at $72^{\circ} \mathrm{C}$ for $5 \mathrm{~min}$. PCR product was visualized on a $4 \%$ agarose gel stained with ethidium bromide.

Gene expression analysis was performed in fresh unstimulated peripheral blood mononuclear cells (PBMCs) separated from $5 \mathrm{cc}$ heparinized blood sample collected form each patient. After density gradient lymphocyte separation using ficoll (1.077), the total RNA was extracted using TriPure Isolation Reagent (Roche Applied Science), according to the manufacturer's protocol. $1 \mu \mathrm{g}$ aliquot of total RNA from each sample was reverse transcribed into single-stranded cDNA using random hexanucleotides primers and expanded reverse transcriptase (Roche Applied Science). cDNA for each sample was subjected to quantitative real-time PCR for internal quantitative control and eNOS (Table 2). All quantitative PCR reactions were performed in mixtures containing cDNA, 10 mL RT2 Real-Time SYBR Green/ROX PCR Master, primer pairs, and nuclease-free water. Each biological replicate was run in duplicate on an ABI step one quantitative PCR system.

\section{Statistical Analysis}

Our gene expression data were normalized against HPRT as our reference gene. Data analysis was conducted using, Livak formula, the $2^{-\Delta \Delta C_{T}}$ method [29]. The significance of differences in gene expression between control and test groups was established by Student's $t$-test considering the fact that our data on eNOS gene fold changes had a normal distribution. In addition, regarding nominal nature of VNTR variables we used crosstabs benefiting from Chi-square test to show significant differences related to our target genotype, a, versus two other genotypes, $a b+b b$. In addition, using
TABLE 1: Baseline characteristics in Iranian subjects with and without CAD.

\begin{tabular}{lcc}
\hline Variable & $\begin{array}{c}\text { With coronary } \\
\text { artery stenosis } \\
\text { CAD }^{+}\end{array}$ & $\begin{array}{c}\text { Without coronary } \\
\text { artery stenosis } \\
\text { CAD }^{-}\end{array}$ \\
\hline Sex (male) N (\%) & $32(60.4)$ & $37(68.5)$ \\
Age $^{£}(y r)$ & $63 \pm 8.5$ & $55 \pm 11$ \\
Current smokers N (\%) & $14(25.9)$ & $7(13.2)$ \\
Hypertension N (\%) & $41(75.9)$ & $27(50.9)$ \\
Diabetes mellitus N (\%) & $29(53.7)$ & $12(22.6)$ \\
Dyslipidemia & $27(50)$ & $13(24.5)$ \\
$\quad$ TChol & $188 \pm 47$ & $175 \pm 38$ \\
TG $^{£}$ & $188 \pm 84$ & $165 \pm 80$ \\
LDL $^{£}$ & $116 \pm 41$ & $118 \pm 37$ \\
HDL $^{£}$ & $44 \pm 17$ & $43 \pm 12$ \\
Past MI $N(\%)$ & $28(51.9)$ & $3(5.7)$ \\
\hline
\end{tabular}

TChol: total cholesterol, TG: triglyceride, LDL: low density lipoprotein, HDL: high-density lipoprotein, Past MI: past history of myocardial infarction, ${ }^{\mathfrak{E}}$ variables are described based on mean \pm standard deviation, $N$ (number) and (\%).

ANOVA and error bars we attempted to investigate the possible changes in eNOS gene expression levels in the presence of individual genotypes. Analysis was performed by SPSS version 16 , and $P \leq 0.05$ was considered as significant.

\section{Results}

The characteristics of patients included in this study are shown in Table 1. We discovered that frequency of patients carrying aa genotype was significantly higher in the $\mathrm{CAD}^{+}$ group compared to $\mathrm{CAD}^{-}$group $(P=0.02, \mathrm{OR}=3.5$; $95 \% \mathrm{CI}$ : $=0.98$ to 16.2 ) (Table 3). Quantitative real-time PCR analysis demonstrated that eNOS expression was upregulated in the $\mathrm{CAD}^{+}$group in comparison with control people (Figure 1); however, in spite of the fact that an upregulated expression was detected, it was not statistically significant in the 0.05 significance level $(P=0.29)$. Additionally, we found that in $\mathrm{CAD}^{-}$patients carrying aa genotype eNOS expression was lower than patients with ab or bb genotypes. This was not observed in $\mathrm{CAD}^{+}$group (Figure 2). The differences were not singnificant $(P>0.05)$.

\section{Discussion}

All NOS gene's isoforms are present in atherosclerosis although there is a powerful evidence pointing out to eNOSdefensive effects on vessels' wall against atherosclerosis [30]. Due to eNOS-protective roles and its contribution to a variety of events in cardiovascular diseases, this gene and its functional polymorphism have attracted great attention [3133].

Controversial results have been reported with respect to eNOS expression in patients with CAD. In a report by De Belder and colleagues they have demonstrated a decrease in both eNOS activity and expression [34], while other studies 
TABLE 2: Primer sequences for real-time PCR quantification.

\begin{tabular}{clc}
\hline Gene & Primer pair sequences & $\begin{array}{c}\text { Amplicon } \\
\text { length }\end{array}$ \\
\hline HPRT & & \\
F & 5'-CCTGGCGTCGTGATTAGTGAT-3' & $131 \mathrm{bp}$ \\
R & 5'-AGACGTTCAGTCCTGTCCATAA-3' & \\
eNOS & & \\
F & $5^{\prime}$-TGGTACATGAGCACTGAGATCG-3' & $148 \mathrm{bp}$ \\
R & 5'-CCACGTTGATTTCCACTGCTG-3' & \\
\hline
\end{tabular}

TABLE 3: eNOS intron 4 VNTR genotype frequencies in $\mathrm{CAD}^{+}$and $\mathrm{CAD}^{-}$group.

\begin{tabular}{|c|c|c|}
\hline eNos VNTR genotype & $\mathrm{CAD}^{+} N(\%)$ & $\mathrm{CAD}^{-} \mathrm{N}(\%)$ \\
\hline $\mathrm{bb}$ & $2855 \%$ & $3066 \%$ \\
\hline$a b$ & $1020 \%$ & $1226 \%$ \\
\hline aa & $1325 \%^{*}$ & $48 \%$ \\
\hline
\end{tabular}

${ }^{*}$ aa versus $\mathrm{ab}+\mathrm{bb} ; P=0.02, \mathrm{OR}=3.5,95 \% \mathrm{CI}=0.98$ to 16.2 .

have shown an increase in the eNOS activity and expression in CAD patients which is regarded as a compensatory mechanism against $\mathrm{CAD}[35,36]$. We have found a nonsignificant increase of eNOS gene expression in unstimulated PBMCs of patients with CAD. We also investigated the association between intron 4, $27 \mathrm{bp}$ VNTR polymorphism and CAD, and we observed that it was significantly associated with CAD in Iranian subjects. Our data shows that carriers of aa genotype had increased risk of CAD. Similarly, Matyar et al., have shown that aa genotype frequency was significantly higher in CAD people in southern Turkey [37]. In addition, an association between this polymorphism and CAD in smokers with severely constricted arteries has been reported by Wang et al. [38]. In another study eNOS 4a allele was considered as an independent risk factor for myocardial infarction (MI) with no considerable difference between smokers and nonsmokers in Japanese population [39]. Likewise, Kunnas et al., have related the polymorphism to both CAD risk and $\mathrm{MI}$ in the Finish middle-aged men [40]. Similarly, there was a relationship between CAD and acute coronary syndrome (ACS) and intron 4 VNTR polymorphism in African-American, Caucasian men, and Koreans [41, 42]. However, other groups have failed to detect a significant difference between CAD and this polymorphism in German and Taiwanese population [43-45].

In addition eNOS polymorphism was not associated with acute myocardial infarction(AMI) and coronary heart disease (CHD) in southern Indian [36] and Greek patients [46]. In a meta-analysis by Casas et al., it was shown that 9 out of the 16 included studies found an increased risk for ischemic heart disease (IHD) in individuals homozygous for the a allele compared with $b$ allele carriers ( $b / b$ plus b/a), but only in one study the difference was statistically significant [33].

The reason for such a discrepancy remains ambiguous. A great number of factors seem to be involved including diagnostic criteria or difference in studied ethnic population. For instance, the frequency of the aa genotype was nearly

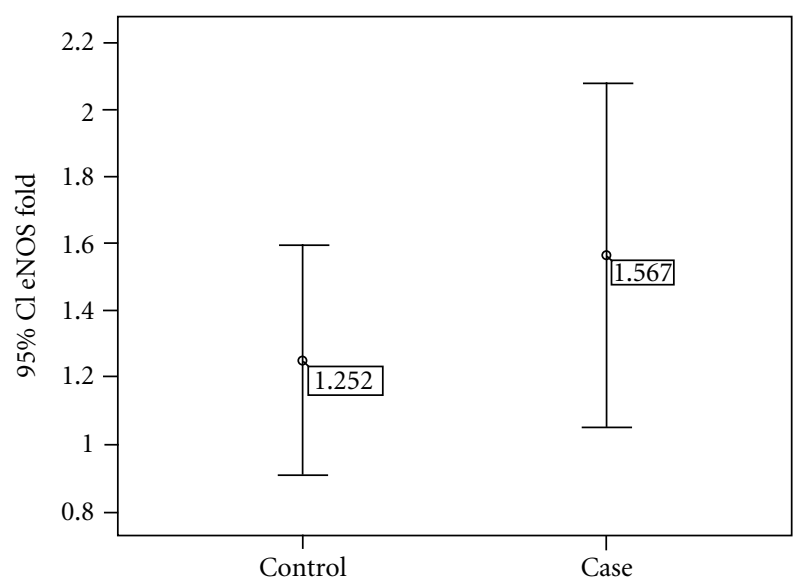

FIGURE 1: eNOS expression in patients with $\mathrm{CAD}^{+}$versus $\mathrm{CAD}^{-}$ Error-Bar shows mean \pm SD mRNA expression normalized against HPRT internal control in patients with $\mathrm{CAD}\left(\mathrm{CAD}^{+}\right)$and patients without $\mathrm{CAD}\left(\mathrm{CAD}^{-}\right)$. There was a nonsignificant increase in eNOS expression in $\mathrm{CAD}^{+}$group versus $\mathrm{CAD}^{-}(P=0.29)$.

$25 \%$ in our subjects which was similar to previously reported results in African-Americans (26 to 30\%) [40, 41], Taiwanese (23.7\%) [45], and south Indian population (24\%) [36]. This was higher than reported frequencies for Spanish (13\%), Turkish (14\%), Japanese (14\%), Caucasian of Australia (17\%), and Koreans (19\%) [36].

Although our results showed no significant difference in eNOS expression among individual genotypes, CAD patients had approximately 4 times higher rate of eNOS expression in the presence of a allele (aa genotype) in comparison with the same genotype in normal group.

Tsukada et al., have found that a strong association between eNOS VNTR and nitric oxide plasma level and mean plasma nitric oxide level in their subjects with aa genotype was about $20 \%$ lower than subjects with bb genotype [47]. Interestingly, an almost similar pattern was observed in our $\mathrm{CAD}^{-}$group, but not in $\mathrm{CAD}^{+}$group. With respect to this issue, Yoon and colleagues have demonstrated that there was a fundamental effect of eNOS4a/b polymorphism on variance of plasma nitric oxide concentrations in Korean population which was dependent on other factors including smoking [32]. The independent association between this polymorphism and plasma NO concentration was not found by other studies [48]. It has been suggested that the effect of this polymorphism on eNOS gene expression might be due to its contribution to exon splicing. Recent data represents that the polymorphism is likely to be source of a $27 \mathrm{nt}$-long RNA derived from pre-mRNA splicing which is able to suppress eNOS expression and may introduce a new class of small RNA [49, 50]. It was shown that a allele in given doses [51] has the capability to produce lower levels of 27nt-small RNA and consequently higher levels of eNOS mRNA compared with cells carrying $b$ allele [50]. It has been shown that such increase in eNOS expression in presence of aa genotype has a strong association with survival in advanced stage of nonsmall cell lung cancer [52]. 


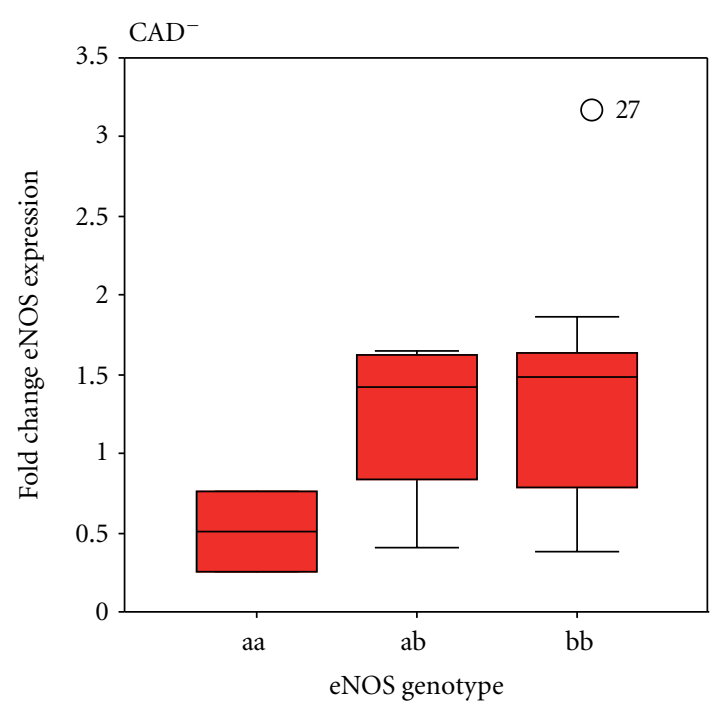

(a)

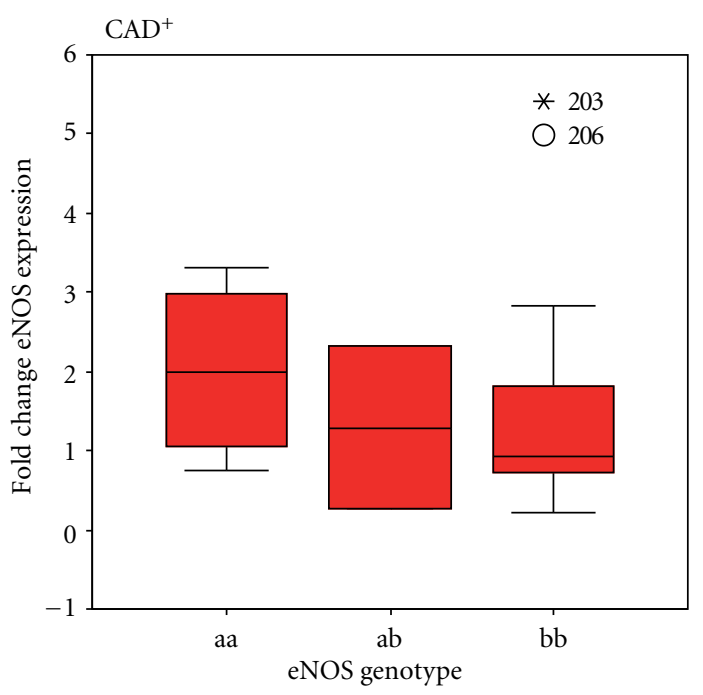

(b)

FIGURE 2: Enos gene expression in patients caryying different intron 4 VNTR genotypes. Box plots shows mRNA expression in (a) controls $\left(\mathrm{CAD}^{-}\right)$and $(\mathrm{b})$ cases $\left(\mathrm{CAD}^{+}\right)$stratified based on VNTR polymorphism with aa, bb, and ab genotypes. There was a decrease in expression of eNOS in patients carrying aa genotype in $\mathrm{CAD}^{-}$group and an increase in eNOS expression in $\mathrm{CAD}^{+}$patients. The differences were not significant $P>0.05$.

Our study was conducted on small number of samples which was one of the main limitations that necessitate careful interpretation of results. Considering the low frequency of a allele further studies on larger population would certainly be more conclusive. However, our data confirms the previous reports, which highlights the importance of eNOS role in CAD. Samples were not available for additional experiments of NOS enzyme expression in PBMCs of patients with CAD. It would be advantageous to examine the NOS expression at the protein level using methods such as western blot compared to mRNA expression level in future studies to validate their role in pathogenesis of CAD.

\section{Conclusion}

In the present study, we demonstrated that eNOS expression was increased in the CAD people compared to normal people. We also showed that eNOS intron $4 \mathrm{~b} / 4 \mathrm{a} 27 \mathrm{bp}-$ VNTR polymorphism was associated with CAD, and aa genotype frequency was significantly higher in CAD people in comparison with normal people. We also illustrated that aa genotype carriers have increased levels of eNOS expression compared with the same genotype in normal group which might have contribution to reduced risk of CAD.

\section{References}

[1] J. F. Peden and M. Farrall, "Thirty-five common variants for coronary artery disease: the fruits of much collaborative labour," Human Molecular Genetics, vol. 20, no. R2, pp. R198-R205, 2011.

[2] N. Jeerooburkhan, L. C. Jones, S. Bujac et al., "Genetic and environmental determinants of plasma nitrogen oxides and risk of ischemic heart disease," Hypertension, vol. 38, no. 5, pp. 1054-1061, 2001.

[3] P. K. BORAH et al., "Polymorphism of angiotensin converting enzyme (insertion/deletion) and endothelial nitric oxide synthase (intron $4 \mathrm{ab}$ ) genes in a population from northeast India," Journal of Genetics, vol. 90, no. 3, pp. e105-e109, 2011.

[4] L. Zhang, "Relationship between polymorphisms of angiotensin-converting enzyme gene insertion/deletion, endothelial nitric oxide synthase gene intron 4 VNTR and risk for cervical cancer," Life Science Journal, vol. 9, no. 2, 2012.

[5] B. Hemmens and B. Mayer, "Enzymology of nitric oxide synthases," Methods in Molecular Biology, vol. 100, pp. 1-32, 1998.

[6] T. J. McCabe, D. Fulton, L. J. Roman, and W. C. Sessa, "Enhanced electron flux and reduced calmodulin dissociation may explain "calcium-independent" eNOS activation by phosphorylation," Journal of Biological Chemistry, vol. 275, no. 9, pp. 6123-6128, 2000.

[7] I. Fleming and R. Busse, "Molecular mechanisms involved in the regulation of the endothelial nitric oxide synthase," American Journal of Physiology-Regulatory Integrative and Comparative Physiology, vol. 284, no. 1, pp. R1-R12, 2003.

[8] M. Schleicher, J. Yu, T. Murata et al., "The Akt1-eNOS axis illustrates the specificity of kinase-substrate relationships in vivo," Science Signaling, vol. 2, no. 82, p. ra41, 2009.

[9] R. M. Rapoport, M. B. Draznin, and F. Murad, "Endotheliumdependent relaxation in rat aorta may be mediated through cyclic GMP-dependent protein phosphorylation," Nature, vol. 306, no. 5939, pp. 174-176, 1983.

[10] U. Forstermann, A. Mulsch, E. Bohme, and R. Busse, "Stimulation of soluble guanylate cyclase by an acetylcholine-induced endothelium-derived factor from rabbit and canine arteries," Circulation Research, vol. 58, no. 4, pp. 531-538, 1986.

[11] L. J. Ignarro, R. G. Harbison, K. S. Wood, and P. J. Kadowitz, "Activation of purified soluble guanylate cyclase by 
endothelium-derived relaxing factor from intrapulmonary artery and vein: stimulation by acetylcholine, bradykinin and arachidonic acid," Journal of Pharmacology and Experimental Therapeutics, vol. 237, no. 3, pp. 893-900, 1986.

[12] U. Alheid, J. C. Frolich, and U. Forstermann, "Endotheliumderived relaxing factor from cultured human endothelial cells inhibits aggregation of human platelets," Thrombosis Research, vol. 47 , no. 5, pp. 561-571, 1987.

[13] M. W. Radomski, R. M. Palmer, and S. Moncada, "The antiaggregating properties of vascular endotheliumml: interactions between prostacyclin and nitric oxide," British Journal of Pharmacology, vol. 92, no. 3, pp. 639-646, 1987.

[14] P. Kubes, M. Suzuki, and D. N. Granger, "Nitric oxide: an endogenous modulator of leukocyte adhesion," Proceedings of the National Academy of Sciences of the United States of America, vol. 88, no. 11, pp. 4651-4655, 1991.

[15] H. Arndt, C. W. Smith, and D. N. Granger, "Leukocyteendothelial cell adhesion in spontaneously hypertensive and normotensive rats," Hypertension, vol. 21, no. 5, pp. 667-673, 1993.

[16] M. Annuk, M. Zilmer, and B. Fellström, "Endotheliumdependent vasodilation and oxidative stress in chronic renal failure: impact on cardiovascular disease," Kidney International, vol. 84, pp. S50-S53, 2003.

[17] S. Dimmeler and A. M. Zeiher, "Nitric oxide-an endothelial cell survival factor," Cell Death and Differentiation, vol. 6, no. 10, pp. 964-968, 1999.

[18] T. Nakaki, M. Nakayama, and R. Kato, "Inhibition by nitric oxide and nitric oxide-producing vasodilators of DNA synthesis in vascular smooth muscle cells," European Journal of Pharmacology, vol. 189, no. 6, pp. 347-353, 1990.

[19] Y. Nunokawa and S. Tanaka, "Interferon $-\gamma$ inhibits proliferation of rat vascular smooth muscle cells by nitric oxide generation," Biochemical and Biophysical Research Communications, vol. 188, no. 1, pp. 409-415, 1992.

[20] P. Vallance, J. Collier, and S. Moncada, "Effects of endotheliumderived nitric oxide on peripheral arteriolar tone in man," The Lancet, vol. 2, no. 8670, pp. 997-1000, 1989.

[21] A. E. Orimadegun, O. Fawole, J. O. Okereke, F. O. Akinbami, and O. Sodeinde, "Increasing burden of childhood severe malaria in a Nigerian tertiary hospital: implication for control," Journal of Tropical Pediatrics, vol. 53, no. 3, pp. 185-189, 2007.

[22] G. Sengoelge, G. Sunder-Plassmann, and W. H. Hörl, "Potential risk for infection and atherosclerosis due to iron therapy," Journal of Renal Nutrition, vol. 15, no. 1, pp. 105-110, 2005.

[23] U. Ramakrishnan, E. Kuklina, and A. D. Stein, "Iron stores and cardiovascular disease risk factors in women of reproductive age in the United States," American Journal of Clinical Nutrition, vol. 76, no. 6, pp. 1256-1260, 2002.

[24] Y. Miyamoto, Y. Saito, N. Kajiyama et al., "Endothelial nitric oxide synthase gene is positively associated with essential hypertension," Hypertension, vol. 32, no. 1, pp. 3-8, 1998.

[25] A. Onat, I. Sari, G. Hergenç et al., "Predictors of abdominal obesity and high susceptibility of cardiometabolic risk to its increments among Turkish women: a prospective populationbased study," Metabolism, vol. 56, no. 3, pp. 348-356, 2007.

[26] O. H. Seoudi et al., "Allelic polymorphism in the endothelial nitric oxide synthase gene in coronary artery diseases," Egyptian Journal of Hospital Medicine, vol. 37, pp. 700-708, 2009.
[27] S. Patkar, B. H. Charita, C. Ramesh, and T. Padma, "High risk of essential hypertension in males with intron 4 VNTR polymorphism of eNOS gene," Indian Journal of Human Genetics, vol. 15, no. 2, pp. 49-53, 2009.

[28] S. Agrawal, V. P. Singh, S. Tewari et al., "Angiotensin-converting enzyme gene polymorphism in coronary artery disease in North India," Indian Heart Journal, vol. 56, no. 1, pp. 44-46, 2004.

[29] K. J. Livak and T. D. Schmittgen, "Analysis of relative gene expression data using real-time quantitative PCR and the $2^{-\Delta \Delta C_{\mathrm{T}}}$ method," Methods, vol. 25, no. 4, pp. 402-408, 2001.

[30] S. S. A. El Gawad et al., "Expression of inducible nitric oxide synthase gene in diabetic and non-diabetic coronary artery disease patients," Inflammation. In press.

[31] J. Loscalzo and G. Welch, "Nitric oxide and its role in the cardiovascular system," Progress in Cardiovascular Diseases, vol. 38, no. 2, pp. 87-104, 1995.

[32] Y. Yoon, J. Song, S. H. Hong, and J. Q. Kim, "Plasma nitric oxide concentrations and nitric oxide synthase gene polymorphisms in coronary artery disease," Clinical Chemistry, vol. 46, no. 10, pp. 1626-1630, 2000.

[33] J. P. Casas, L. E. Bautista, S. E. Humphries, and A. D. Hingorani, "Endothelial nitric oxide synthase genotype and ischemic heart disease: meta-analysis of 26 studies involving 23028 subjects," Circulation, vol. 109, no. 11, pp. 1359-1365, 2004.

[34] A. J. de Belder, M. W. Radomski, H. J. F. Why et al., "Nitric oxide synthase activities in human myocardium," The Lancet, vol. 341, no. 8837, pp. 84-85, 1993.

[35] B. Stein, T. Eschenhagen, J. Rüdiger, H. Scholz, U. Förstermann, and I. Gath, "Increased expression of constitutive nitric oxide synthase III, but not inducible nitric oxide synthase II, in human heart failure," Journal of the American College of Cardiology, vol. 32, no. 5, pp. 1179-1186, 1998.

[36] T. Angeline, W. Isabel, and G. J. Tsongalis, "Endothelial nitric oxide gene polymorphisms, nitric oxide production and coronary artery disease risk in a South Indian population," Experimental and Molecular Pathology, vol. 89, no. 3, pp. 205-208, 2010.

[37] S. Matyar, G. Attila, E. Acartürk, O. Akpinar, and T. Inal, "eNOS gene intron $4 \mathrm{a} / \mathrm{b}$ VNTR polymorphism is a risk factor for coronary artery disease in Southern Turkey," Clinica Chimica Acta, vol. 354, no. 1-2, pp. 153-158, 2005.

[38] X. L. Wang, A. S. Sim, R. F. Badenhop, R. Michael Mccredie, and D. E. L. Wilcken, "A smoking-dependent risk of coronary artery disease associated with a polymorphism of the endothelial nitric oxide synthase gene," Nature Medicine, vol. 2, no. 1, pp. 41-45, 1996.

[39] S. Ichihara, Y. Yamada, T. Fujimura, N. Nakashima, and M. Yokota, "Association of a polymorphism of the endothelial constitutive nitric oxide synthase gene with myocardial infarction in the Japanese population," American Journal of Cardiology, vol. 81, no. 1, pp. 83-86, 1998.

[40] T. A. Kunnas, E. Ilveskoski, T. Niskakangas et al., "Association of the endothelial nitric oxide synthase gene polymorphism with risk of coronary artery disease and myocardial infarction in middle-aged men," Journal of Molecular Medicine, vol. 80, no. 9, pp. 605-609, 2002.

[41] S. Rao, H. Austin, M. N. Davidoff, and A. M. Zafari, "Endothelial nitric oxide synthase intron 4 polymorphism is a marker for coronary artery disease in African-American and Caucasian men," Ethnicity and Disease, vol. 15, no. 2, pp. 191-197, 2005.

[42] K. W. Park, K. H. You, S. Oh et al., "Association of endothelial constitutive nitric oxide synthase gene polymorphism with 
acute coronary syndrome in Koreans," Heart, vol. 90, no. 3, pp. 282-285, 2004.

[43] A. Gardemann, J. Lohre, S. Cayci, N. Katz, H. Tillmanns, and W. Haberbosch, "The T allele of the missense $\mathrm{Glu}_{298}$ Asp endothelial nitric oxide synthase gene polymorphism is associated with coronary heart disease in younger individuals with high atherosclerotic risk profile," Atherosclerosis, vol. 160, no. 1, pp. 167-175, 2002.

[44] Y. W. Wu, C. M. Lee, S. M. Hsu, and Y. T. Lee, "Association between endothelial nitric oxide synthase polymorphisms and the risk of premature coronary artery disease in Taiwan," Journal of Internal Medicine of Taiwan, vol. 14, no. 1, pp. 1-10, 2003.

[45] N. T. Lin, M. J. Lee, R. P. Lee, A. I. C. Hong, and H. I. Chen, "Analysis of endothelial nitric oxide synthase gene polymorphisms with cardiovascular diseases in eastern Taiwan," Chinese Journal of Physiology, vol. 51, no. 1, pp. 42-47, 2008.

[46] M. Vasilakou, V. Votteas, C. Kasparian et al., "Lack of association between endothelial nitric oxide synthase gene polymorphisms and risk of premature coronary artery disease in the Greek population," Acta Cardiologica, vol. 63, no. 5, pp. 609-614, 2008.

[47] T. Tsukada, K. Yokoyama, T. Arai et al., "Evidence of association of the ecNOS gene polymorphism with plasma NO metabolite levels in humans," Biochemical and Biophysical Research Communications, vol. 245, no. 1, pp. 190-193, 1998.

[48] S. Salimi, M. Firoozrai, I. Nourmohammadi, M. Shabani, and A. Mohebbi, "Endothelial nitric oxide synthase gene intron4 VNTR polymorphism in patients with coronary artery disease in Iran," Indian Journal of Medical Research, vol. 124, no. 6, pp. 683-688, 2006.

[49] M. X. Zhang, C. Zhang, Y. H. Shen et al., "Effect of $27 \mathrm{nt}$ small RNA on endothelial nitric-oxide synthase expression," Molecular Biology of the Cell, vol. 19, no. 9, pp. 3997-4005, 2008.

[50] M. X. Zhang, C. Zhang, Y. H. Shen et al., "Biogenesis of short intronic repeat 27-nucleotide small RNA from endothelial nitric-oxide synthase gene," Journal of Biological Chemistry, vol. 283, no. 21, pp. 14685-14693, 2008.

[51] D. Senthil, M. Raveendran, Y. H. Shen et al., "Genotypedependent expression of endothelial nitric oxide synthase (eNOS) and its regulatory proteins in cultured endothelial cells," DNA and Cell Biology, vol. 24, no. 4, pp. 218-224, 2005.

[52] S. Fujita, K. Masago, Y. Hatachi et al., "Genetic polymorphisms in the endothelial nitric oxide synthase gene correlate with overall survival in advanced non-small-cell lung cancer patients treated with platinum-based doublet chemotherapy," BMC Medical Genetics, vol. 11, article no. 167, 2010. 


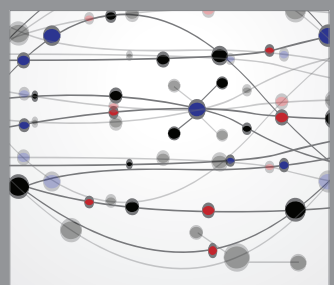

The Scientific World Journal
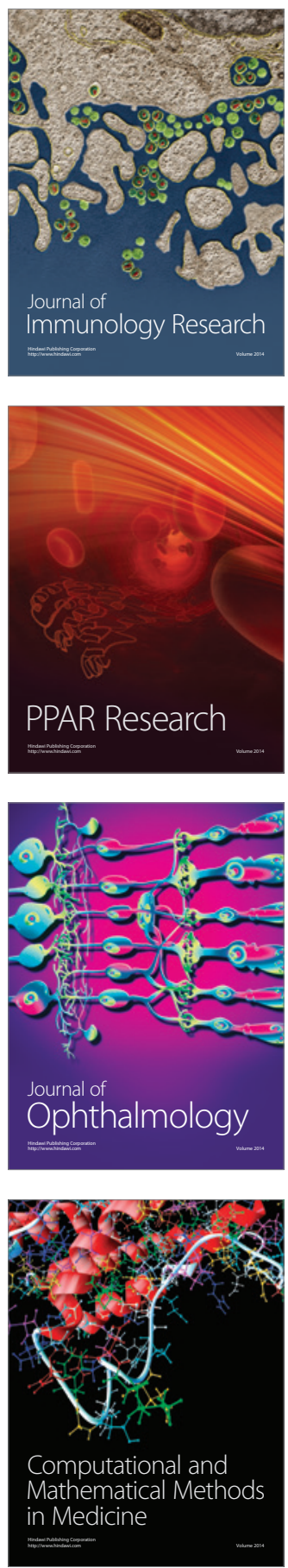

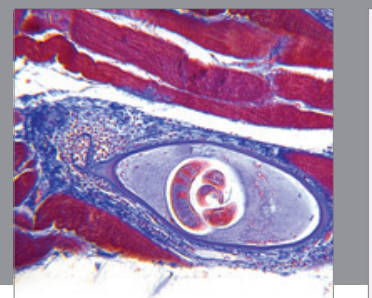

Gastroenterology

Research and Practice
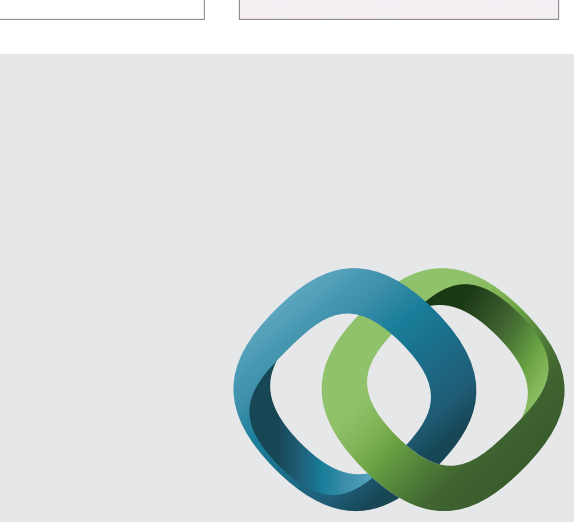

\section{Hindawi}

Submit your manuscripts at

http://www.hindawi.com
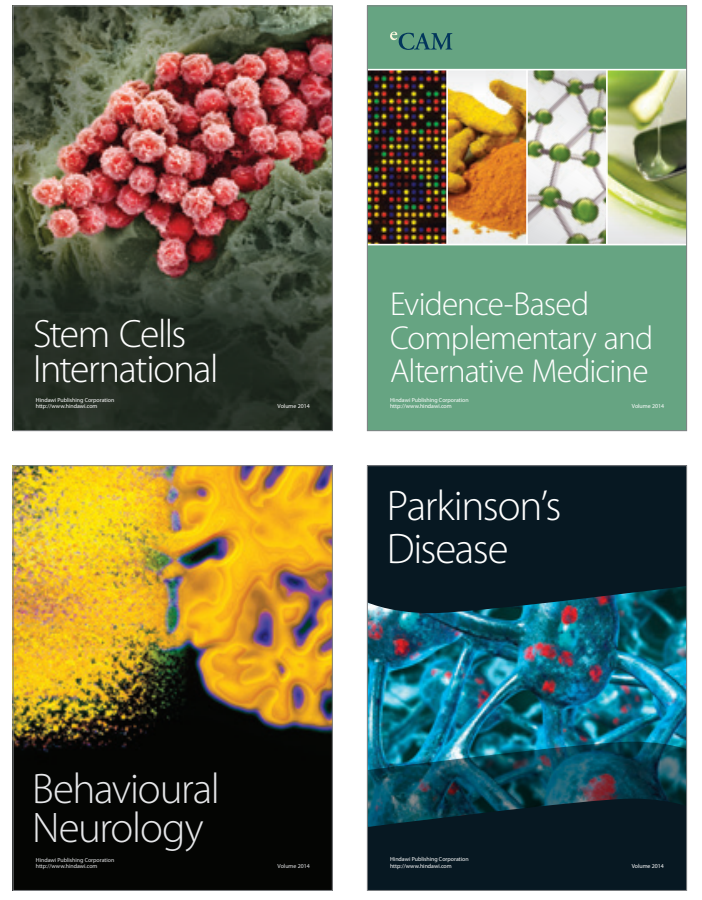
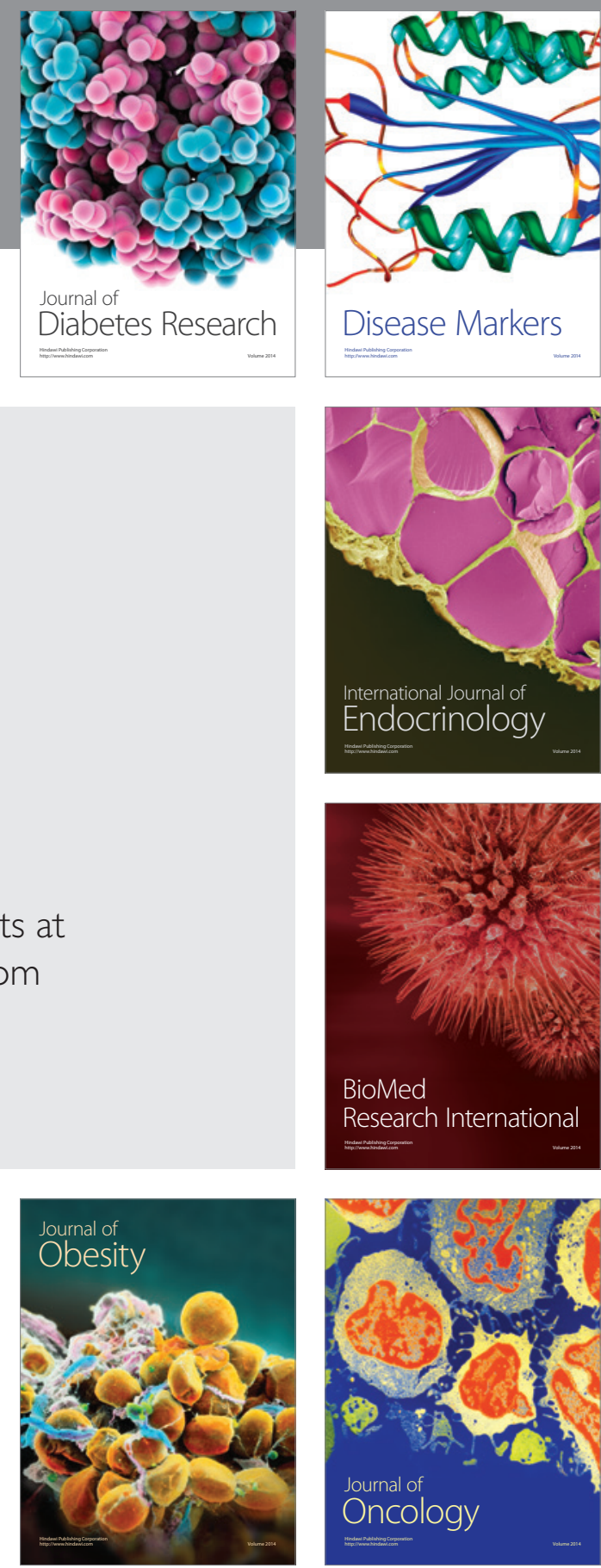

Disease Markers
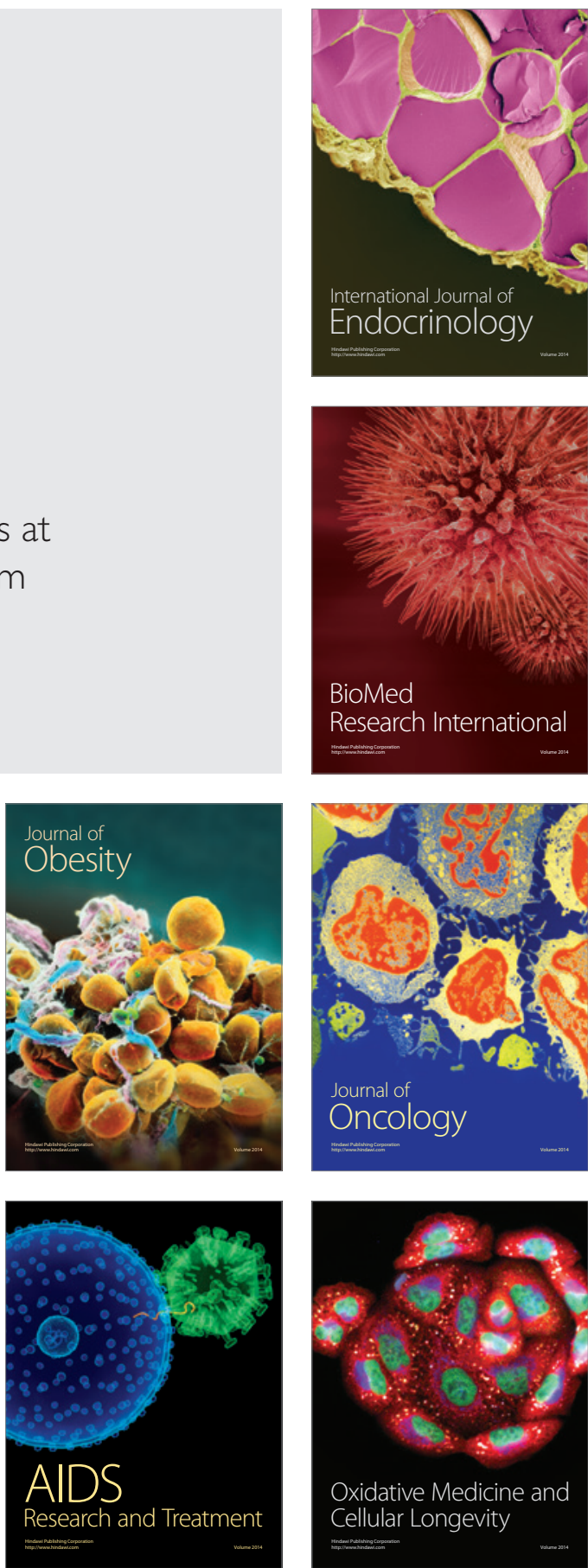